\title{
Interinext
}

\section{Empirical analysis of 'level of comfort' among international workers at multinational firms}

\author{
Vijesh Jain ${ }^{1 A}$ and Susana Costa e Silva ${ }^{B}$ \\ AInstitute of Technology and Science, Ghaziabad, India \\ ${ }^{B}$ Católica Porto Business School, Universidade Católica Portuguesa, Porto, Portugal
}

\begin{tabular}{|c|}
\hline ARTICLE DETAILS \\
\hline Article history: \\
\hline Received September 20, 2016 \\
\hline Accepted August 04, 2017 \\
\hline Available online in August 31, 2017 \\
\hline Double Blind Review System \\
\hline Scientific Editor \\
\hline Ilan Avrıchır \\
\hline Keywords: \\
\hline Cultural Distance \\
\hline Cross Culture Study \\
\hline Comfort with Foreign Cultures \\
\hline Culture to Culture Comfort \\
\hline
\end{tabular}

\begin{abstract}
The research is grounded in responses of multicultural team members at multinational workplaces from 14 different countries that provided their preferences or choice of nationalities of members that they would like to hire/work with. Results show clear differences in 'levels of comfort' displayed by managers and members having particular national cultural background in what concerns their preferences and choices of colleagues with origins from other national cultures. These variations results into designation of rankings to the destination regions based on preference by the respondents from the source countries. Results also show a somewhat common pattern of preferences irrespective of their national origins that has been described.
\end{abstract}

(C) 2017 Internext | ESPM. All rights reserved.

\section{INTRODUCTION}

In 20th century term 'culture' emerged as central theme of 'anthropology', usually referring to a range of human phenomenon that cannot be attributed to genetic inheritance. For example Hoebel (1966) described culture as an integrated system of learned behavior patterns which are characteristics of members of a society and which are not a result of biological inheritance. Nine Curt (1984) defines culture as, "The bearer of human wisdom that includes wealth of human behaviors, beliefs, attitudes, values and experiences of immense worth" (p.3). Culture is also defined as, "an integrated pattern of human behavior including thoughts, communication, ways of interacting, roles and relationships, and expected behaviors, beliefs, values, practices and customs"(Taylor 1997, cited in Denboba et al. 1998: S-47). According to Chamberlain (2005), culture refers to "the values, norms and traditions that affect how individuals of a particular group perceive, think, behave and make judgment

\footnotetext{
${ }^{1}$ Correspondent author: vijeshjain@its.edu.in
}

about the world around them" (p.197). In addition, the concept of 'culture' also carries attributes which are most 'dear' or which are most 'offensive' to a member of a culture. These attributes too could be different for different cultures across the world.

Cultural ethos and preferences varies a lot not only among continents but also among countries. This brings us to the concept of 'national culture' (Hofstede, 1980, 1983, 1984). National culture has to do with differences among national cultural background of individuals in their societal or business environment. The concept has also to do with the way those manifested differences may influence business decisions at the international level. National culture can be interpreted as "a common frame of reference or logic by which members of a society view organizations, the environment, and their relations to one another" (Geletkanycz 1997, p. 617). According to most authors of cultural studies, these differences emerges from several factors such as ethnical differences, ethical differences, geographical 
differences, moral differences, historical differences, political differences, linguistic differences and religious differences (Matondo, JPM, 2012).

In business environment, during communication between persons of different national cultural backgrounds, such differences can play an important role which may manifest into certain degree of friction, discomfort and inability to appreciate 'these differences and different ways of thinking of persons of foreign cultures' (Shenkar and Zeira, 1992, p. 5575), potentially affecting the performance of the project teams (Shenkar, 2001, p. 519), leading us to study of a phenomenon, we describe in this paper as 'level of comfort' which signify a continuum of 'intercultural comfort' to 'intercultural discomfort' among workers with different national background. Within this continuum a value is associated, which quantifies the so called 'level of comfort'. Therefore, a lower value of 'preference score' signifies a higher 'level of comfort' between two specific team members coming from two specific national origins and signifying different cultural background.

In both profit and non-profit organizations while operating globally these cultural differences are prominently visible and have to be dealt with care. But besides being an important concept in what comes to dealing with people from different firms, operating in different cultural backgrounds, the concept of 'level of comfort' is also important for managing multicultural teams. In fact, managing employees of different national cultural backgrounds, due to the discomfort that it might cause, poses major challenge for team leaders (Kayworth, Timothy and Leidner, 2000).

On the basis of the concept of national cultures and therefore about the 'level of comfort', it is possible to study workplace cultural differences (in terms of 'level of comfort') with more clarity. Therefore, study of variations of 'level of comfort' among team members of different national cultural background can be very useful to manage diversity in both societal as well as organizational contexts. Currently, organizations are harvesting strategic advantages from cultural diversity in project teams (Love, 2010). These strategic advantages, either to profit and non-profit organizations may include improved human resource management, enriched team performance, better change management, better 'headquarter - subsidiaries' relations, and better talent management, among others. Study of differences in 'level of comfort' arising out of these cultural differences can also be very useful, for instance, in protecting international students and/or immigrants, who are more likely to experience frequent cultural shocks when working or studying in a country which is distinct in culture from their own native country and its specific culture. Studies related to the study of variations of 'level of comfort' among team members of different cultural background, can be used to train them to adapt to host cultures, appreciate them and blend with them, instead of living with fear, hate, complex, or living by adoption of bicultural identities. As for business concerns, international managers would also benefit from prevention from these risks, what would end-up in being very good for the sake of overall international business performance.

This study tried to find out if 'level of comfort' differences, among team members of multicultural teams at multinational workplaces, as an independent cultural dimension is unique to different national cultures or conversely there exists a commonality of differences in preferences of 'local culture employees' with 'foreign culture colleagues' among responses coming from MNE employees of different national background. Such outcomes of cultural behavior can be distinctive to national cultures and generalization can be useful for this purpose, if done in international context when comparisons among countries are useful (Hofstede, 1991). Therefore, using an empirical comparative cross cultural study, it may be possible to map the 'variable propensity' of 'level of comfort' among team members, coming from different national cultural backgrounds, for example, among one pair of employees with two specific national cultures and therefore we may be able to designate rankings to the most preferred national cultures from the 'destination' regions.

However, it would require a large amount of resources and time for cross cultural researchers to map all such cultural pairs globally. In this study we have attempted to perform some of these comparisons with a limited set of cultural pairs, using respondent data from a set of MNE employees from 14 different national cultures. Therefore the scope of this study is limited to studying the 'level of comfort' among team members at multinational workplaces only. Therefore, 'level of comfort' herein refers to the 'intercultural comfort' among a pair of employees from two specific national cultural backgrounds. 
It should be noted there that 'level of comfort' is often confused with different cultural concepts like 'cultural competence' or 'cultural distance'. In addition, there are several cultural dimensions suggested in different comparative cultural studies which may seem to explain the phenomenon of 'intercultural comfort'. However, none of these researches have been able to clearly define phenomenon of 'level of comfort' at multinational work teams from the 'culture to culture' perspective i.e. among cultural pairs. Some of these studies and models do explain, somewhat indirectly, the reaction of persons of local culture to their interaction with persons of foreign cultural background. However, such explanations are not complete, qualitative in nature, explain general reactions only and do not touch upon the concept of 'level of comfort' among a specific national culture to another specific culture at multinational workplaces. This research article tries to explain such differences in 'level of comfort' more directly, discretely, quantitatively and among selected cultural pairs. Hence, the objective of this research is to map the 'level of comfort' of a selected set of MNE employees working with multinational enterprises (MNEs) from 'respondent' nations with other teammates coming from different cultural backgrounds from a selected set of 'destination' nations or regions of the world. For example, with the proposed approach we have quantified the 'level of comfort' of Italian MNE employees with colleagues coming from, say a North American country or from a Middle Eastern country. We can also compare, for instance, the varying 'level of comfort' of Australian MNE employees with colleagues coming from African nations, South Asia or Central Asia on 'pair' basis. In other words, in the current study, we have tried to find the dynamics of this intercultural comfort among different MNE employees coming from a combination of different cultural backgrounds. Following literature review should help us in understanding the concept of 'level of comfort 'and its foundation in more detail.

\section{LITERATURE REVIEW}

Comparative international studies to record cultural differences are broadly based on certain popular cultural models, so called 'onion models' (Schein, 2010) or 'multi-layered models' (Homburg, et al., 2000) or 'multi-dimensional models' (Houkamau, et al., 2010). Most popular among these are those suggested by Hofstede (1980, 1991), Fons
Trompenaars (1997), Shalom Schwartz (1994, 2006), GLOBE study (House, et al., 2001), Smith (1995), Inglehart (1997) and others. More recently several authors of cultural research have also suggested the concept of 'cultural competence' which seems to have come closer to explaining the reaction of local cultures with foreign cultures during their different set of encounters including workplace encounters and therefore touches upon the phenomenon of 'level of comfort' somewhat indirectly. Some of these classical studies on national cultural differences are discussed in the following paragraphs for more clarity on the central construct of this research article.

\subsection{Cultural Dimensions and Cultural Differences}

One of the most important and earliest studies in modern times, done to understand cultural differences among international cultures, is the 'five dimensions model' of cultural differences as suggested by Hofstede (1980, 1982, and 1986).In 1980, Geert Hofstede published 'Culture's Consequences', a monumental work that represented more than a decade of research. In this book, along with subsequent editions, Hofstede established that 'people carry mental programs that are developed in the family in early childhood and which are reinforced in schools and organizations', assuming that 'these mental programs contain a component of national culture' (Hofstede, 2001, p. xix). He categorized the differences in mental programming by identifying initially four cultural dimensions. Hofstede and Bond (1984) later identified a fifth dimension after research on behaviors of Chinese professionals. These five cultural dimensions have contributed enormously to a deeper understanding of the theories and dynamics of cross cultural management based on different categories of mental programming. The variables identified in these researches assumed that all reactions in working relationship or production of behavior, thereof, will be reflected at a workplace assimilating the social, organizational and personal 'values and beliefs'.

The reason Hofstede focused on individual countries for his study was his belief that differences and similarities in cultural patterns were easily identifiable and meaningful at the nation-state level. He attributed the cultures measured in each nationstate to 'historical roots' and certain 'mechanisms in societies that permit the maintenance of stability in 
cultural patterns across generations' (Hofstede 2001, p.11). Hofstede continues by declaring that institutions 'reinforce the societal norms and the ecological conditions that led to their establishment' (2001, p.11). Hofstede (2001) also offers his judgment on how host societies react to the arrival of foreigners. According to the author, the reaction is assessed in three steps. Step (1): the locals are curious about how different the foreigners are (i.e., the 'zoo' effect). Step (2): Ethnocentrism, its occurrence leads to the locals perceiving their cultures as superior to those of the foreigners; and step (3), which takes the longer than the others to be reached - and which, in fact, may never be reached in some societies - is 'polycentrism', where locals evaluate the foreigner as having different standards because they are different. In this last step, there is no judgment on the part of the locals whether the foreigners' standards are better or worse than their own; it is merely inferred that they are different. Since the last step takes longer to emerge if at all it emerges, we claim that the concept of 'level of comfort' becomes significant and is manifested in the working relationship among team members in multicultural international teams.

In an open-market economy, businesses are expected to assume a polycentric view to best serve local and foreign customers, thus enabling them to adapt their products and services to the needs of cross cultural customers. This could allow them to gain a competitive advantage in saturated local markets. The above accounts of Hofstede give a new perspective of the intercultural interaction and were discussed in detail before the development of the questionnaire by the expert team which participated in the Delphi sessions for the purpose.

Trompenaar's (1997) seven dimensions model of national cultural differences, specifies more layers to explain national cultural differences - Universalism vs. particularism (What is more important, rules or relationships?); Individualism vs. collectivism (communitarianism) (Do we function in a group or as individuals?); Neutral vs. emotional (Do we display our emotions?); Specific vs. diffuse (How separate we keep our private and working lives); Achievement vs. ascription (Do we have to prove ourselves to receive status or is it given to us?); Sequential vs. synchronic (Do we do things one at a time or several things at once?); Internal vs. external control (Do we control our environment or are we controlled by it?). The work on this model is based on $1000+$ corporate training programs done by the author. Here, Trompenaars (1997) tried to understand whether the management concepts as taught in American business schools can be used as they are, to train people of different European countries. The author of that study indicates from his experience that the concepts vary from country to country. Therefore international managers need to work on several premises. These premises emanates from local sensitivities which vary from one country to another. The author concludes there are visible and invisible ways in which local culture impacts the organization. When you compare same global organization within several countries you will visibly find the organization across nations are not different and therefore 'local culture' free. But when you go deeper you find that is not true. There are invisible factors that differentiate same organization in one country to another due to the impact of local cultures. These suggestions by the author hint at the enquiry of cross cultural group interaction process in multicultural teams, especially in terms of 'level of comfort' to enquire about those invisible factors.

GLOBE (Global Leadership and Organizational Behavior Effectiveness) study empirically established nine cultural dimensions that make it possible to capture the similarities and/or differences in norms, values, beliefs -and practices-among societies. These layers are -1 ) Power Distance: The degree to which members of a society expect power to be distributed equally; 2) Uncertainty Avoidance: The extent to which a society, organization, or group relies on social norms, rules, and procedures to alleviate unpredictability of future events.; 3) Humane Orientation: The degree to which a collective encourages and rewards individuals for being fair, altruistic, generous, caring, and kind to others.; 4) Collectivism I: (Institutional) The degree to which organizational and societal institutional practices encourage and reward collective distribution of resources and collective action.; 5) Collectivism II: (In-Group) The degree to which individuals express pride, loyalty, and cohesiveness in their organizations or families.; 6) Assertiveness: The degree to which individuals are assertive, confrontational, and aggressive in their relationships with others.; 7) Gender Egalitarianism: The degree to which a collective minimizes gender Inequality; 8) Future Orientation: The extent to which individuals engage in future-oriented behaviors such as delaying gratification, planning, and investing in the future.; 
9) Performance Orientation: The degree to which a collective encourages and rewards group members for performance improvement and excellence (House, et al., 2001). Using these cultural dimensions, in the ways similar to the work of Hofstede (1980, 1991), GLOBE study also identified different cultural groups across the world, which may likely to show similar cultures.

GLOBE also studied the preferred leadership styles in different cultural clusters and concluded studies on six styles of leaders who are the preferred by each cluster group but the level of preference of the leader style vary from cluster to cluster. For example 'performance oriented leader style' is highly preferred in Anglo and Germanic cultures, while 'self or group - protective leader style' is least preferred in these cultures. These differences in preferred leadership styles across cultures further reinforce the need to study intercultural comfort among multicultural team members at workplaces in terms of the concept of 'level of comfort' as defined above. This study also gives new insights into the way forward for the current study with respect to the development of the questionnaire and selection of respondent and destination cultures, using methods described in detail in next section.

\subsection{Cultural competence}

One of the concepts of cross cultural management which is closely related to the concept of 'level of comfort', is 'intercultural competence'. Cultural competence refers to the ability of individuals to interact effectively with persons of different cultures. Such abilities can be developed through broadening one's worldview, knowledge of other cultures, cross cultural training, developing right attitude towards cultural differences. Developing cultural competency can result into improving the ability to interact, understand, and communicate effectively with people across cultures (Campinha-Bacote,1991). The discomfort among employees of different cultural backgrounds may also be the result of differences in terms of 'cultural competence' of a person of one culture to understand an alien culture. According to Cross et al. (1989), basic requirement of desired cultural competence has five dimensions to it -1 ) Level of empathy to other cultures, 2) Knowledge of other cultures, 3) Self-confidence (knowledge of one's own desires, expectations, strengths and weaknesses), 4) Cultural Identity (Knowledge of one's own culture), 5) Emotional Stability. Due to obvious variations in these five elements from one culture to another culture, propensity to feel comfort with a person of a foreign cultural background may vary from one culture to another and among different pairs of cultures. The level of such comfort of one culture with another can also emerge from individual traits like - being cultural savvy, astuteness, appreciation, literacy level, adaptability, terrain, expertise, competency, awareness, intelligence and understanding (Selmeski, 2007). The concept gives new insights into the current enquiry on the concept of 'level of comfort' and provides a strong foundation to the methodology we are going to use in the current study.

Based on the discussion made above, it seems that 'level of comfort' of employees among different combinations of 'culture to culture' pairs may vary due to possible seasoning of minds of these employees from childhood to their present age, and due to the specific societal environment they grew in. Hofstede (2001, p11) has also suggested the 'cultural consequences' being the result of things like outside influence, societal norms and origins of the persons. Therefore it is prudent to investigate if the 'level of comfort' among MNE employees varies based on different combinations of cultural backgrounds.

Therefore we suggest our hypothesis as follows:

h1: 'Level of comfort' (defined as above) among
MNE employees of different pairs of national
cultural background vary among different
combinations of national background.

This paper has tested above hypothesis on the data collected from MNE employees who are working or have worked in international project teams, and coming from a set of different 'respondent' national cultures with a set of such employee coming from another set of 'destination' regions/countries. Countries included in the respondent set were based on the convenience sampling. We collected data from several countries and we included only those respondent countries from where we were able to collect reasonable amount of responses. Countries/regions included in the destination set were based a perception scaling and consultative exercise involving a five-stage iteration based on Delphi technique described in next section. 


\section{RESEARCH METHODOLOGY}

Our enquiry of intercultural variation in terms of 'level of comfort' among different combinations of cultural pairs involves certain questions, the answers to which are to be found. These questions refer to things like why and how do people of one culture may feel more comfortable to another culture but not so comfortable to yet another culture and other similar questions as described in Table 1 . These questions were the result of a brain storming session with a team of experts as described later in this section. To answer these questions we conducted an exploratory research. In it, we resorted to a quantitative analysis involving use of Likert scale to map the responses in terms of degree of agreement to different questions and corresponding to different destination cultures.
Using a survey approach, we tried to answer the research questions based on the Likert scale in order to understand the phenomenon of variations in 'level of comfort' among cultural pairs as discussed earlier. The choice of these variables and corresponding questions was based on the method described in the next paragraph.

There can be several conceivable variables which can define 'level of comfort'. The approaches to defining these variables can be different. Current study took into consideration a 'perception scaling and consultative' method to devise survey questions using Delphi technique with the help of a set of 100 cross cultural experts and students of cross cultural studies. Several rounds of Delphi sessions were conducted among the volunteers to understand what

\section{Tab.1}

Questions / items included in the survey instrument*

\section{Question}

If you were an employer yourself, and if you happen to choose from among a set of candidates with similar skills and requisites, if you will be thinking of their country of origin as a factor of choice, please mention your order of preference of the hires.

As a resident in your city / country, if you happen to choose a new house having neighbor of a foreign origin, is it likely that your choice of housing unit will be influenced by the country of origin of your neighbor. If you will be thinking of their country of origin as a factor of choice, please mention you order of preference of your neighbor's country origins.

As an employee if you happen to choose from among a set of job offers with similar potential and remuneration, you may be thinking of the country of origin of your boss. If you will be thinking of their country of origin as a factor of choice, please mention you order of preference.

As an employee if you happen to choose from among a set of multinational company (MNE) with similar prospects to work abroad. If you will be thinking of their country of origin as a factor of choice, please mention you order of preference.

As a potential migrant to a foreign country getting a new job from several choices of countries, you may be thinking of the country as a factor of choice of your new job. If you will be thinking of their country of origin as a factor of choice, please mention you order of preference.

If you were yourself a businessman and you had to choose a global business partner. If you will be thinking of their country of origin as a factor of choice, please mention your order of preference of your partner's country of origin.

If you would think of spending your holidays in near future you would prefer to go which of the following destinations? List the destinations in order of your preferred choices.

\section{Purpose of the question}

How the national origin of potential candidate affect respondent's decision to hire someone for respondent's own business, can give strong indication of your cultural preferences and therefore respondent's comfort level with different alien cultures.

How the national origin of potential neighbor affect respondent's decision to live along side can give strong indication of respondent's cultural preferences and therefore respondent's comfort level with different alien cultures.

How the national origin of the potential employer affect respondent's decision to 'work for' can give strong indication of respondent's cultural preferences and therefore respondent's comfort level with different alien cultures.

Respondent's choice of employer based on the country to work in can give strong indication of respondent's cultural preferences and therefore respondent's comfort level with different alien cultures.

Respondent's choice of country to 'work in' can give strong indication of respondent's cultural preferences and therefore respondent's comfort level with different alien cultures.

Respondent's choice of a business partner based on his or her national origin, can give strong indication of respondent's cultural preferences and therefore respondent's comfort level with different alien cultures.

Respondent's choice of a holiday destination based on the place location in a particular country, can give strong indication of respondent's cultural preferences and therefore respondent's comfort level with different alien cultures.

Source: Delphi sessions as described 
variables constitute the central construct i.e. 'Level of comfort' (Harold et al, 1975). Questions which emerged as explaining variables to the enquiry are given in Table 1. These questions formed the part of the survey questionnaire. The choices of these questions were based on testing the cultural preferences of the respondents in different situations and purposes. Respondent were the MNE employees from different 'source' countries.

Against the questions discussed in Table 1, respondent MNE employees were given choices of a set of 14 countries / regions of the world to choose their level of preferences of the country / region on a 5 point Likert scale (as already explained above). These destination countries/ regions were - North America, Middle America, South America, Europe (West), Europe (East), Central Asia, South Asia, South East Asia, China, Japan, Korea, Australia, Africa, Middle East.

Based on this questionnaire, respondent's data was collected and collated online. The data was based on convenience sampling using approximately 650 responses from employees of multinational firms, working in multi-cultural teams on international projects, located in more than 15 source countries. On review of the online data collected from these countries, it was found that in case of one country, number of respondents were too less to be considered. On final review it was observed that valid and sufficient numbers of responses were available from 14 respondent countries as given in Table 2 .

Before using the questionnaire and data, the survey instrument was tested for repeatability and reliability. For repeatability test, in particular, 50 respondents were used in order to assess the repeatability. These respondents completed the questionnaire two times. Between the two measurements there was a period of three to four days. The repeatability of questionnaire was also evaluated by using McDonald Omega which is a measure of generalizability of the test items. It varies between 0 to 1 . Omega can be interpreted as the square of the correlation between the scale score and the latent variable common to all the indicators in the infinite universe of indicators of which the scale indicators are a subset (McDonald, 1999, page 89). Evaluation of the internal consistency of the observed variables of the CFC questionnaire was carried out by calculating the Standardized Cronbach Alpha coefficient and calculating reliability estimates.
According to Hair et al (1998), it is generally agreed upon to be 0.7 , the lower limit of .05 as proposed by Nunnally (1978). Large Cronbach Alpha values indicate a high consistency of the questions of which the sub-scale is consisted. The 'Cronbach Alpha if item deleted' index was used to see if there were questions that reduced the internal consistency of the questionnaire and therefore may have to be excluded. The results of all these tests were favorable and valid.

The sample was spread to several companies and several verticals within organizations to avoid polarization of the same cultural group while responding to questions. The validity was established on entire set of 556 responses from 14 countries. This sample of 556 responses became the basis for the study as described in Table 2.

Tab. 2

Sample structure for the cross cultural study

\begin{tabular}{llll}
\hline $\begin{array}{l}\text { Name of the } \\
\text { country }\end{array}$ & $\begin{array}{l}\text { Sample } \\
\text { Size }\end{array}$ & No of Males & $\begin{array}{l}\text { No of } \\
\text { Females }\end{array}$ \\
\hline Italy & 84 & $40(48 \%)$ & $44(52 \%)$ \\
Argentina & 31 & $10(32 \%)$ & $21(68 \%)$ \\
Australia & 32 & $12(37 \%)$ & $20(63 \%)$ \\
Canada & 32 & $11(34 \%)$ & $21(66 \%)$ \\
China & 40 & $25(63 \%)$ & $15(37 \%)$ \\
Germany & 38 & $13(34 \%)$ & $25(66 \%)$ \\
Japan & 32 & $15(47 \%)$ & $17(53 \%)$ \\
Nigeria & 32 & $20(63 \%)$ & $12(27 \%)$ \\
Pakistan & 35 & $28(80 \%)$ & $7(20 \%)$ \\
Saudi Arabia & 35 & $27(77 \%)$ & $8(23 \%)$ \\
U.K. & 45 & $20(44 \%)$ & $25(56 \%)$ \\
USA & 34 & $14(41 \%)$ & $20(59 \%)$ \\
India & 54 & $30(55 \%)$ & $24(45 \%)$ \\
Portugal & 32 & $15(47 \%)$ & $17(53 \%)$ \\
\hline Total & 556 & $280(50 \%)$ & $276(50 \%)$ \\
\hline
\end{tabular}

Source: Elaborated by the authors.

As described above, the respondent MNE employees were asked to respond to the questions on a 5-point Likert's scale, higher score indicating 'lower level of comfort' of respondents with a specific geographically alien culture (referred to as the 'destination' culture). All the responses to the questionnaire were added to a single input sheet into SPSS program and 'mean scores' were compared for several questions with respect to corresponding destinations, with the independent variable as the 'respondent country MNE employees'. The 'mean scores' were also compared for each question with respect to 14 'destination countries MNE employees'. 
Tab. 3

Mean scores of preferences of Italian MNE employees.

\begin{tabular}{lcccccccc}
\hline \multicolumn{1}{c}{ ITALY } & $\begin{array}{c}\text { Pref. as } \\
\text { Employer }\end{array}$ & $\begin{array}{c}\text { Pref. as } \\
\text { Resident }\end{array}$ & $\begin{array}{c}\text { Pref. of MNE } \\
\text { as Employee }\end{array}$ & $\begin{array}{c}\text { Pref. of country } \\
\text { as Employee }\end{array}$ & $\begin{array}{c}\text { Pref. as } \\
\text { Migrant }\end{array}$ & $\begin{array}{c}\text { Pref. as } \\
\text { Businessman }\end{array}$ & $\begin{array}{c}\text { Pref. as } \\
\text { Tourist }\end{array}$ & $\begin{array}{c}\text { Mean } \\
\text { North America }\end{array}$ \\
2.07 & 2.02 & 1.88 & 2.04 & 1.89 & 1.99 & 1.76 & 1.95 \\
Central America & 2.48 & 2.27 & 2.21 & 2.36 & 2.30 & 2.40 & 1.79 & 2.26 \\
South America & 2.67 & 2.39 & 2.30 & 2.43 & 2.35 & 2.57 & 1.63 & 2.33 \\
West Europe & 1.94 & 1.88 & 1.81 & 2.01 & 1.75 & 1.95 & 1.79 & 1.88 \\
East Europe & 2.48 & 2.65 & 2.56 & 2.58 & 2.76 & 2.62 & 2.17 & 2.55 \\
Central Asia & 2.54 & 2.58 & 2.67 & 2.67 & 2.95 & 2.60 & 2.30 & 2.61 \\
South Asia & 2.52 & 2.55 & 2.65 & 2.68 & 2.93 & 2.57 & 2.19 & 2.59 \\
South East Asia & 2.46 & 2.56 & 2.68 & 2.71 & 2.90 & 2.46 & 2.19 & 2.57 \\
China & 2.43 & 2.83 & 2.81 & 2.56 & 2.86 & 2.36 & 2.30 & 2.59 \\
Japan & 1.88 & 2.12 & 2.27 & 2.14 & 2.19 & 2.02 & 1.93 & 2.08 \\
S. Korea & 2.30 & 2.39 & 2.54 & 2.55 & 2.83 & 2.39 & 2.63 & 2.52 \\
Australia & 2.07 & 1.95 & 1.94 & 1.99 & 1.89 & 2.06 & 1.58 & 1.93 \\
Africa & 2.65 & 2.65 & 2.60 & 2.79 & 2.86 & 2.79 & 1.89 & 2.60 \\
Middle East & 2.77 & 2.90 & 2.70 & 2.67 & 3.02 & 2.56 & 2.45 & 2.73 \\
\hline Mean scale scores & 2.38 & 2.41 & 2.4 & 2.44 & 2.53 & 2.38 & 2.04 \\
\hline
\end{tabular}

Source: Elaborated by the authors.

For example question related to respondent's preference of employees of a particular cultural origin, as an employer, were compared and tabulated (like for an example as described in Table 3). All questions indicated the level of preference among respondents from a single respondent country and are given in rows in each table for each respondent country. The average mean scores were tabulated in different tables. These questions were used as the different scales to understand the overall 'level of comfort' of respondent with a particular 'destination' region. These scales were as per the questionnaire structure, as discussed above.

\section{RESULTS AND OBSERVATIONS}

Based on the above clustering of the items (questions) in the questionnaire, following insights were obtained with respect to comfort scales of questionnaire using the final primary data from 556 respondents across 14 countries. Mean scores of preferences with respect to 'level of comfort' of MNE employees of respondent countries were recorded for all the 14 respondent countries. As an example, process of calculating the mean score of preference of Italian MNE employees is given below ${ }^{2}$.

\subsection{Level of comfort of Italian MNE employees}

Cultural preferences of Italian MNE employees vary across 14 regions of the world. Table 3 gives a visual representation based on responses from Italy.
As can be seen in Table 2, if they were themselves employers, Italians MNE employees, would have been most comfortable with persons from Japan and least comfortable with people from Middle Eastern countries, to hire as 'employees'. As 'residents', Italian MNE employees are likely to most prefer West Europeans and least prefer people of Middle East origin as 'neighbors'. As 'subordinates', Italian MNE employees are likely to most prefer a West European and least prefer a Chinese as their 'boss'. As 'employees' Italian MNE employees are likely to most prefer an Australian Company and least prefer an African company to work with. Italian MNE employees are most willing to migrate to West European destination and least willing to migrate to Middle Eastern region. If they were businessmen, Italian MNE employees would have been least likely to be 'partner' in business with Africans and most likely to be 'partner' with West Europeans. Italian MNE employees are most willing to visit Australia and least willing to visit South Korea as 'tourists'. Overall, it appears that Italian MNE employees are most comfortable with West European cultures and least comfortable South Korean culture.

In the same way mean preference scores of other respondent (source) countries were calculated and tabulate but could not be included in the text of this article as explained above. Based on these average mean scores, rankings of the countries were done as explained below.

\footnotetext{
2 Due to paucity of the article space, other tables indicating the similar responses from other 13 countries are not included in this article.
} 
Tab. 4

Mean preference scores and ranking scores based on respondent MNE employees.

\begin{tabular}{|c|c|c|c|c|c|c|c|c|c|c|c|c|c|c|}
\hline Country / Rank & Nam & Cam & Sam & WEur & EEur & CAsia & SAsia & SE Asia & China & Japan & S. Korea & Aust. & Africa & M. East \\
\hline \multirow{2}{*}{ Italy } & 1.95 & 2.26 & 2.33 & 1.88 & 2.55 & 2.61 & 2.59 & 2.57 & 2.59 & 2.08 & 2.52 & 1.93 & 2.60 & 2.73 \\
\hline & 3 & 5 & 6 & 1 & 8 & 13 & 10 & 9 & 11 & 4 & 7 & 2 & 12 & 14 \\
\hline \multirow[t]{2}{*}{ India } & 2.04 & 2.36 & 2.44 & 2.06 & 2.29 & 2.32 & 2.39 & 2.33 & 2.66 & 2.28 & 2.65 & 2.41 & 2.84 & 2.87 \\
\hline & 1 & 7 & 10 & 2 & 4 & 5 & 8 & 6 & 12 & 3 & 11 & 9 & 13 & 14 \\
\hline \multirow[t]{2}{*}{ Germany } & 2.32 & 2.51 & 2.62 & 2.24 & 2.41 & 2.56 & 2.61 & 2.47 & 2.61 & 2.31 & 2.68 & 2.40 & 2.80 & 3.03 \\
\hline & 3 & 7 & 11 & 1 & 5 & 8 & 10 & 6 & 9 & 2 & 12 & 4 & 13 & 14 \\
\hline \multirow[t]{2}{*}{ USA } & 2.31 & 2.74 & 2.68 & 2.36 & 2.67 & 2.70 & 2.64 & 2.54 & 2.72 & 2.42 & 2.75 & 2.48 & 2.86 & 3.00 \\
\hline & 1 & 11 & 8 & 2 & 7 & 9 & 6 & 5 & 10 & 3 & 12 & 4 & 13 & 14 \\
\hline \multirow[t]{2}{*}{ China } & 1.82 & 2.26 & 2.48 & 1.93 & 2.46 & 2.48 & 2.66 & 2.47 & 2.30 & 2.35 & 2.64 & 2.33 & 2.79 & 2.99 \\
\hline & 1 & 3 & 9 & 2 & 7 & 10 & 12 & 8 & 4 & 6 & 11 & 5 & 13 & 14 \\
\hline \multirow[t]{2}{*}{ Saudi Arabia } & 2.16 & 2.53 & 2.65 & 2.06 & 2.42 & 2.81 & 2.60 & 2.27 & 2.77 & 2.39 & 2.53 & 2.22 & 2.95 & 2.77 \\
\hline & 2 & 7 & 10 & 1 & 6 & 13 & 9 & 4 & 12 & 5 & 8 & 3 & 14 & 11 \\
\hline \multirow[t]{2}{*}{ Pak } & 2.45 & 2.90 & 2.70 & 2.47 & 2.69 & 2.73 & 2.24 & 2.38 & 2.75 & 2.62 & 2.79 & 2.62 & 2.79 & 3.10 \\
\hline & 3 & 13 & 8 & 4 & 7 & 9 & 1 & 2 & 10 & 5 & 11 & 5 & 11 & 14 \\
\hline \multirow[t]{2}{*}{ Nigeria } & 1.97 & 2.81 & 2.64 & 2.22 & 2.33 & 2.57 & 2.42 & 2.36 & 2.67 & 2.27 & 2.75 & 2.59 & 3.07 & 2.88 \\
\hline & 1 & 12 & 9 & 2 & 4 & 7 & 6 & 5 & 10 & 3 & 11 & 8 & 14 & 13 \\
\hline \multirow[t]{2}{*}{ UK } & 2.12 & 2.68 & 2.62 & 1.97 & 2.27 & 2.56 & 2.68 & 2.49 & 2.69 & 2.28 & 2.64 & 2.25 & 3.03 & 2.97 \\
\hline & 2 & 10 & 8 & 1 & 4 & 7 & 11 & 6 & 12 & 5 & 9 & 3 & 14 & 13 \\
\hline \multirow[t]{2}{*}{ Argentina } & 1.90 & 2.85 & 3.01 & 2.01 & 2.60 & 2.95 & 2.85 & 2.65 & 2.81 & 1.82 & 2.69 & 2.19 & 3.32 & 3.42 \\
\hline & 2 & 9 & 12 & 3 & 5 & 11 & 10 & 6 & 8 & 1 & 7 & 4 & 13 & 14 \\
\hline \multirow[t]{2}{*}{ Canada } & 2.15 & 2.58 & 2.44 & 1.92 & 2.23 & 2.68 & 2.78 & 2.59 & 2.94 & 2.42 & 3.04 & 2.28 & 2.99 & 3.44 \\
\hline & 2 & 7 & 6 & 1 & 3 & 9 & 10 & 8 & 11 & 5 & 13 & 4 & 12 & 14 \\
\hline \multirow[t]{2}{*}{ Japan } & 2.22 & 2.55 & 2.55 & 2.30 & 2.36 & 2.54 & 2.57 & 2.35 & 2.75 & 2.46 & 2.67 & 2.47 & 2.84 & 3.08 \\
\hline & 1 & 8 & 9 & 2 & 4 & 7 & 10 & 3 & 12 & 5 & 11 & 6 & 13 & 14 \\
\hline \multirow[t]{2}{*}{ Portugal } & 1.99 & 2.69 & 2.81 & 2.27 & 2.45 & 2.90 & 2.60 & 2.70 & 2.91 & 1.71 & 2.53 & 2.04 & 2.55 & 3.55 \\
\hline & 2 & 9 & 11 & 4 & 5 & 12 & 8 & 10 & 13 & 1 & 6 & 3 & 7 & 14 \\
\hline \multirow[t]{2}{*}{ Australia } & 2.38 & 2.50 & 2.78 & 2.49 & 2.59 & 2.64 & 2.74 & 2.71 & 2.67 & 2.55 & 2.79 & 2.33 & 2.83 & 2.99 \\
\hline & 2 & 4 & 11 & 3 & 6 & 7 & 10 & 9 & 8 & 5 & 12 & 1 & 13 & 14 \\
\hline Score Average & 2.13 & 2.59 & 2.63 & 2.16 & 2.45 & 2.65 & 2.60 & 2.49 & 2.70 & 2.28 & 2.69 & 2.32 & 2.88 & 3.06 \\
\hline Rank Average & 1.86 & 8.00 & 9.14 & 2.07 & 5.36 & 9.07 & 8.64 & 6.21 & 10.14 & 3.79 & 10.07 & 4.36 & 12.50 & 13.64 \\
\hline
\end{tabular}

Abbreviations: NAm - North America; Cam - Central America; Sam - South America; WEur - West Europe; EEur - East Europe; CAsia Central Asia; SAsia - South Asia; SEAsia - South East Asia; Aust - Australia; M. East - Middle East

\subsection{Ranking of respondent countries on their overall level of comfort with specific regions}

In line with above observations a ranking of MNE employee's preferences of the 'respondent countries' is done based on 'average preference scores'. The overall 'mean' preference scores 'based on all questions in the questionnaire are tabulated in Table 4. The final notional overall ranking of the 'destination countries/region' based on the overall comfort level of MNE employees from respondent countries as analyzed by above tabular analysis appears to be as in Table 5 .

Figure 1 below depicts the common continuum of 'level of comfort' of MNE employees irrespective of their own cultural origin.

Table 6 below gives the extreme preferences of MNE employees from individual country background.
Tab. 5

Common ranking based on level of comfort of MNE employees from different respondent countries

\begin{tabular}{ll}
\hline Destination Country/Region & Rank* \\
\hline North America & 1 \\
West Europe & 2 \\
Japan & 3 \\
Australia & 4 \\
East Europe & 5 \\
South East Asia & 6 \\
Central America & 7 \\
South Asia & 8 \\
South America & 9 \\
Central Asia & 10 \\
S. Korea & 11 \\
China & 12 \\
Africa & 13 \\
Middle East & 14 \\
\hline
\end{tabular}

Source: Elaborated by the authors.

A visual investigation of the extreme ends of the preferences as given in table above indicates 


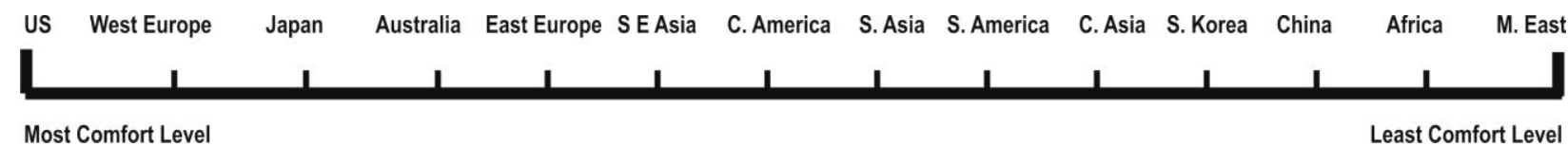

Most Comfort Level

Least Comfort Level

Fig. 1

Common continuum of 'level of comfort' of MNE employees

Source: Elaborated by the authors.

somewhat common pattern among MNE employees of source countries preferences. In other words we notice that MNE employees of most respondent countries find themselves most comfortable with colleagues coming from US and / or West Europe background while find it comparatively least comfortable with colleagues with Middle East or African background.

Tab. 6

Extreme ends of the preferences of MNE employees from respondent countries

\begin{tabular}{ccc}
\hline Respondent Country & Most comfort with colleagues of & Least comfort with colleagues of \\
\hline Italy & West Europe & South Korea \\
India & US/West Europe & Middle East \\
Germany & West Europe & Middle East \\
US & US/West Europe & Middle East \\
China & US & Middle East \\
Saudi Arabia & West Europe & Africa \\
Pakistan & South Asia & Middle East \\
Nigeria & US & Africa \\
UK & West Europe & Africa \\
Argentina & US & Middle East \\
Canada & West Europe & Middle East \\
Japan & US & Middle East \\
Portugal & US & Middle East \\
Australia & US & Middle East \\
\hline
\end{tabular}

Source: Elaborated by the authors.

\section{CONCLUSIONS AND DISCUSSIONS}

From the above analysis it can be concluded that the 'level of intercultural comfort' among different MNE employees of different local cultures varies from one 'destination country or region' to another. However there is a common pattern across source cultures which indicate clear commonality in differences of preferences of MNE employees of their colleague's cultural origins. Among the countries studied it is seems there are local cultures among MNE employees which are more comfortable to foreign colleagues and therefore foreign cultures of specific geographical region than others. It may be noted that among the countries studied Middle Eastern countries ranks most unfavorably and there could be strong cultural differences which make most MNE employees of most respondent cultures comparatively less comfortable to this region. At the same time there is a definite level of comfort of all the MNE employees of respondent countries with colleagues of North American and West European origins. Therefore our alternative hypothesis that level of comfort among 'cultural pairs' vary is accepted.

Another important observations from the results 
study also gives an insight into the nature of comfort level, 'question wise'. It should be noted that question of choice of region as a tourist destination, indicate quite distinct scores. It appears that this particular variable is most unrelated to other variables describing 'level of comfort' level phenomenon. A detailed study from a psychological perspective into the choice of respondent country's choice of tourist destination should give new insights into this phenomenon.

One important theoretical finding of this study is that at the least in the MNE workplaces, we find that cultural origins of employees plays a significant role in there being comfortable or not so comfortable with colleagues of different cultural background, necessitating right intercultural training for its employees. This finding reinforces the conclusions of the 'culture at work' report of IPSOS and British Council (2013) that explains the importance and value of intercultural skills at workplaces. In addition the construct of this research study gives insights into what constitute the so called 'level of comfort' which is manifested in the answer to specific questions taken up in the research methodology of this study. The novelty of this study is that it provides a model for assessing the intercultural comfort among colleagues with different cultural backgrounds in MNE workplaces. This model constitutes a few important questions which form the building blocks of this study and as explained in the construct of this research. The results and methodology of this study can be used and replicated to study similar intercultural comfort in situations other than MNE workplaces, for example, to study the intercultural equations among local and migrant population in a city, or among students with different nationality in international universities and other similar situations.

Moreover, this research itself being a good indicator of the 'level of comfort' between 'culture to culture' in MNE workplaces, more data should be collected to further review the results of this study. This may be important to understand variations of results emerging from for example within different industrial sectors which these MNEs belong to or size of MNEs or other categories of multinational corporations.

\section{REFERENCES}

- Campinha-Bacote, J. (1991). The Process of Cultural Competence: A Culturally Competent Model of Care. Wyoming, Ohio: Transcultural C.A.R.E Associates
- Chamberlain, SP (2005). Recognizing and responding to cultural differences in the education of culturally and linguistically diverse learners. Intervention in School \& Clinic, 40(4), p.195-211.

- Cross, T., Bazron, B., Dennis, K., \& Isaacs, M. (1989). Towards A Culturally Competent System of Care, Volume I. Washington, DC: Georgetown University Child Development Center, CASSP Technical Assistance Center.

- Curt, Nine (1984). Non-verbal Communication in Puerto Rico. Cambridge, Massachusetts: p.3-5

- Denboba, DL et al. (1998). Reducing Health Disparities through Cultural Competence. Journal of Health Education 29 (5, Supplement): p.S47-53

- Geletkanycz, M. A. (1997). The salience of 'culture's consequences': The effects of cultural values on top executive commitment to the status quo. Strategic Management Journal, I8(S), p.615-634.

- Hair, JF, Anderson, RE, Tatham, RL and Black, WC (1998). Multivariate data analysis, Prentice Hall International, New Jersey.

- Harold A. Linstone, Murray Turoff (1975), The Delphi Method: Techniques and Applications, Reading, Mass.: Addison-Wesley, ISBN 978-0-201-04294-8

- Hoebel, Adamson (1966). Anthropology: Study of Man, McGraw-Hill; 3rd edition

- House, R., Javidan, M., \&Dorfman, PW (2001). Project GLOBE: An introduction in Applied Psychology: An International Review, 50(4), p.489-505.

- Hofstede, G. (1980). Culture's consequences: International differences in work-related values. Beverly Hills, CA: Sage.

- Hofstede, G. (1983). The Cultural Relativity of Organizational Practices and Theories, Journal of International Business Studies, 14, 1983

- Hofstede, G. (1984). Culture's consequences: International differences in work-related values. Newbury Park, CA: Sage

- Hofstede, G. (1987). "The Applicability of McGregor's Theories in South East Asia," Journal of Management Development, Vol. 6, No. 3, p. 9-18.

- Hoststede, G. (1991). Culture and organizations: Software of the mind. London: McGraw-Hill.

- Hoststede, G. (1996). "Riding the waves of commerce: a test of Trompenaars' "model" of national culture differences", in: International Journal of Intercultural Relations 20(2): p. 189-198.

- Hofstede, G. (2001). Culture's consequences: Comparing values, behaviors, institutions, and organizations across nations. Thousand Oaks, CA: Sage.

- Hofstede, G. (2006). What did GLOBE really measure? Researchers' minds versus respondents' minds? Journal of International Business Studies, p. 37, 882-896. 
- Hofstede, G. \& Bond, M.H. (1984). "Hofstede's Culture Dimensions: An Independent Validation Using Rokeach's Value Survey." Journal of Cross-Cultural Psychology, 15(4): p.417-433

- Homburg, C \& Pflesser, C., (2000). A Multiple-Layer Model of Market-Oriented Organizational Culture: Measurement Issues and Performance Outcomes, Journal of Marketing Research, Vol. 37, No. 4, pp. 449462

- Houkamau, CA, \& Sibley, CG (2010). The MultiDimensional Model of Māori Identity and Cultural Engagement. New Zealand Journal of Psychology, 39, 828.

- Inglehart, R. (1997). Modernization and PostModernization: Cultural, Economic, and Political Change in 43 Societies. Princeton, N.J.: Princeton University Press, 1997

- Kayworth, Timothy and Leidner, Dorthy (2000). "The Global Virtual Manager: A Perspective for Success," European Management Journal, 18 (2): p.183-194.

- Love, A. (2010). "Diversity as a Strategic Advantage", BusinessWeek. Web article. Retrieved from http://www.businessweek.com/ managing/ content/ may2010/ca20100513_748402 on 2014-12-20

- Madison, Greg (2006). "Existential Migration". Existential Analysis 17 (2): 238-60.

- MATONDO, J.P.M (2012). Cross-Cultural Values Comparison between Chinese and Sub-Saharan Africans, International Journal of Business and Social Science, Vol. 3 No. 11; p.38-45

- Nunnally, J. C. (1978). Psychometric theory (2nd ed.). New York, NY: McGraw-Hill.

- Rathje, S. (2007). Intercultural Competence: The Status and Future of a Controversial Concept. Journal for Language and Intercultural Communication, 7(4), p.254-266
- Schwartz, SH (2006). Value orientations: Measurement, antecedents and consequences across nations. In $\mathrm{R}$. Jowell, C. Roberts, R. Fitzgerald, \& G. Eva (Eds.), Measuring attitudes cross-nationally - lessons from the European Social Survey. London: Sage

- Selmeski, BR (2007). Military cross-cultural competence: Core concepts and individual development. Kingston: Royal Military College of Canada Centre for Security, Armed Forces, \& Society.

- Schein, E. H. (2010). Organizational Culture and Leadership, 4 edition. Jossey-Bass, ISBN-10: 0470190604, ISBN-13: 978-0470190609.

- Shenkar, O. \&Zeira, Y. (1992). Role conflict and role ambiguity of CEO's in international joint ventures'. Journal of International Business Studies, 23 (1), p.5575.

- Shenker, O. (2001). Cultural distance revisited: Towards a more rigorous conceptualization and measurement of Cultural Differences., Journal of International Business Studies; Third Quarter; 32, 3; ABI/INFORM Global, p. 519

- Smith, PB and Peterson, MF (1995). "Beyond Value Comparisons: Sources Used to Give Meaning to Management Work Events in Twenty-Nine Countries." Paper presented at the annual meeting of the Academy of Management, Vancouver, Canada.

- Trompenaars F., and Hampden-Turner, C. (1997). Riding the waves of culture: Understanding diversity in global business (2nd Ed.). New York: McGraw-Hill.

- Witte, A. (2012). "Making the Case for a Post-National Cultural Analysis of Organizations," Journal of Management Inquiry 21:141. Originally published online on 13 September 2011.

- Yeager, KL \& Fredrick, MN (2012). Developing diverse teams to improve performance in the organizational setting, European Journal of Training and Development, Vol. 36 No. 4, 2012, pp. 388-408.

\section{About the authors}

- Vijesh Jain is PhD in Marketing (University of Mysore, Mysore, India). Professor and Chiarperson (Economics Department) at Institute of Technolology and Science, Ghaziabad, India. Researcher in the field of Cross Cultural Management, International Cultures, International Business. E-mail: vijeshjain@its.edu.in

- Susana Costa e Silva is PhD in Marketing (University College Dublin, Ireland). Lecturer at Católica Porto Business School, Universidade Católica Portuguesa, Porto, Portugal. Researcher in the fields of Strategic Marketing International Marketing and Social Marketing. E-mail: ssilva@porto.ucp.pt 


\title{
Análise empírica do "nível de conforto" em trabalhadores internacionais nas empresas multinacionais
}

\author{
Vijesh Jain ${ }^{A}$ e Susana Costa e Silva ${ }^{B}$ \\ A Institute of Technology and Scienc, Ghaziabad, India \\ ${ }^{B}$ Católica Porto Business School, Universidade Católica Portuguesa, Porto, Portugal
}

\section{DETALHES DO ARTIGO}

\section{Histórico do artigo:}

Recebido em 20 de setembro de 2016

Aceito em 04 de agosto de 2017

Disponível online em 31 de agosto de 2017

Sistema de Revisão "Double Blind Review"

Editor científico:

Ilan Avrichir

\section{Palavras-chaves:}

Distância Cultural

Estudo de Cultura Cruzada

Conforto com Culturas Estrangeiras

Conforto de Cultura para Cultura

\begin{abstract}
RESUMO
O multiculturalismo em equipes de trabalho é comum em empresas multinacionais (EMN). Observa-se que o multiculturalismo pode melhorar o desempenho da equipe (Yeager et al., 2011). No entanto, coloca diferentes desafios. Um dos maiores desafios relaciona-se com a variação no "nível de conforto" entre os membros da equipe que vêm de diferentes contextos culturais. Um membro com um background cultural pode ficar mais confortável com outro membro que vem de um contexto cultural específico do que com outro membro que vem de outro background cultural. Este estudo foca-se no conforto cultural entre os membros da equipe com base em pares culturais para ver quem fica mais confortável com quem com respeito à sua identidade cultural, com base em suas origens nacionais e por quê. A pesquisa baseia-se em respostas de membros da equipe multicultural em locais de trabalho multinacionais de 14 países diferentes, que forneceram suas preferências ou escolha de nacionalidades de membros com quem eles desejariam contratar / trabalhar. Os resultados mostram diferenças claras em "níveis de conforto" exibidos pelos gerentes e membros, que têm um contexto cultural nacional particular, no que diz respeito às suas preferências e escolhas de colegas com origens de outras culturas nacionais. Essas variações resultam na elaboração de rankings para as regiões de destino, com base na preferência dos inquiridos dos países de origem. Os resultados também mostram um padrão de preferências comuns, independentemente de suas origens nacionais, que foi descrita.
\end{abstract}

(c) 2017 Internext | ESPM. Todos os direitos reservados!

To cite this article:

Jain, V. \& Costa e Silva, S. (2017). Empirical analysis of 'level of comfort' among international workers at multinational firms. Internext - Revista Eletrônica de Negócios Internacionais, 12 (2), 45-57. DOI: http:// dx.doi.org/10.18568/1980-4865.12245-57

To access this article: $h t t p: / / d x$. doi.org/10.18568/1980-4865.12245-57 